\title{
Plant Calcium Signaling in Response to Potassium Deficiency
}

\author{
Xiaoping Wang ${ }^{1,2}$, Ling Hao ${ }^{1,2}$, Biping Zhu ${ }^{1}$ and Zhonghao Jiang ${ }^{1,2, * \mathbb{C}}$ \\ 1 Shenzhen Key Laboratory of Marine Bioresource \& Eco-environmental Science, \\ Guangdong Engineering Research Center for Marine Algal Biotechnology, \\ College of Life Sciences and Oceanography, Shenzhen University, Shenzhen 518060, China; \\ wangxp@szu.edu.cn (X.W.); haoling2017@szu.edu.cn (L.H.); Musyfreak@hotmail.com (B.Z.) \\ 2 Key Laboratory of Optoelectronic Devices and Systems of Ministry of Education and Guangdong Province, \\ College of Optoelectronic Engineering, Shenzhen University, Shenzhen 518060, China \\ * Correspondence: jamesjiang0220@hotmail.com; Tel.: +86-159-6889-0346
}

Received: 1 October 2018; Accepted: 1 November 2018; Published: 3 November 2018 updates

\begin{abstract}
Potassium $\left(\mathrm{K}^{+}\right)$is an essential macronutrient of living cells and is the most abundant cation in the cytosol. $\mathrm{K}^{+}$plays a role in several physiological processes that support plant growth and development. However, soil $\mathrm{K}^{+}$availability is very low and variable, which leads to severe reductions in plant growth and yield. Various $\mathrm{K}^{+}$shortage-activated signaling cascades exist. Among these, calcium signaling is the most important signaling system within plant cells. This review is focused on the possible roles of calcium signaling in plant responses to low- $\mathrm{K}^{+}$stress. In plants, intracellular calcium levels are first altered in response to $\mathrm{K}^{+}$deficiency, resulting in calcium signatures that exhibit temporal and spatial features. In addition, calcium channels located within the root epidermis and root hair zone can then be activated by hyperpolarization of plasma membrane (PM) in response to low- $\mathrm{K}^{+}$stress. Afterward, calcium sensors, including calmodulin (CaM), CaM-like protein (CML), calcium-dependent protein kinase (CDPK), and calcineurin B-like protein (CBL), can act in the sensing of $\mathrm{K}^{+}$deprivation. In particular, the important components regarding CBL/CBL-interacting protein kinase (CBL/CIPK) complexes-involved in plant responses to $\mathrm{K}^{+}$deficiency are also discussed.
\end{abstract}

Keywords: calcium signaling; potassium deficiency; calcium sensors; CBLs; CIPKs

\section{Introduction}

Potassium $\left(\mathrm{K}^{+}\right)$is an essential macronutrient and is essential for plant growth and development [1] $\mathrm{K}^{+}$is associated with or involved in several physiological processes that support plant growth and development, such as photosynthesis, enzyme activation, osmoregulation, electrical neutralization, $\mathrm{pH}$ and ion homeostasis, anion-cation balance, membrane electrical potential, protein and starch synthesis, sugar and nutrient transport, and stomatal movement [2]. $\mathrm{K}^{+}$also plays a major role in enhancing the tolerance of plants to various stresses $[3,4]$. The concentrations of $\mathrm{K}^{+}$in the soil solution range from only $0.1-1 \mathrm{mM}$, and can be much lower at the root surface due to local depletion [5]. $\mathrm{K}^{+}$ deficiency in most arable fields is limiting for optimal plant growth [6,7]. $\mathrm{K}^{+}$deprivation leads to a strong increase in chlorophyll degradation; $\mathrm{K}^{+}$deficiency-related symptoms include brown scorching and curling of leaf tips, as well as interveinal chlorosis [8]. Reduced leaf area under $\mathrm{K}^{+}$deficiency has also been reported $[9,10]$. In addition, $\mathrm{K}^{+}$deficiency affects root development, as primary root growth is negatively affected [11,12]. Various $\mathrm{K}^{+}$shortage-activated signaling cascades exist; these cascades involve reactive oxygen species (ROS) [13], phytohormones (ethylene, auxin, and jasmonic acid) [14,15], calcium [16], and phosphatidic acid [17]. Among these signaling cascades, calcium signaling is the most important signaling system within plant cells. In this review, the possible roles of calcium signaling in plant responses to low- $\mathrm{K}^{+}$stress are discussed (Figure 1). 


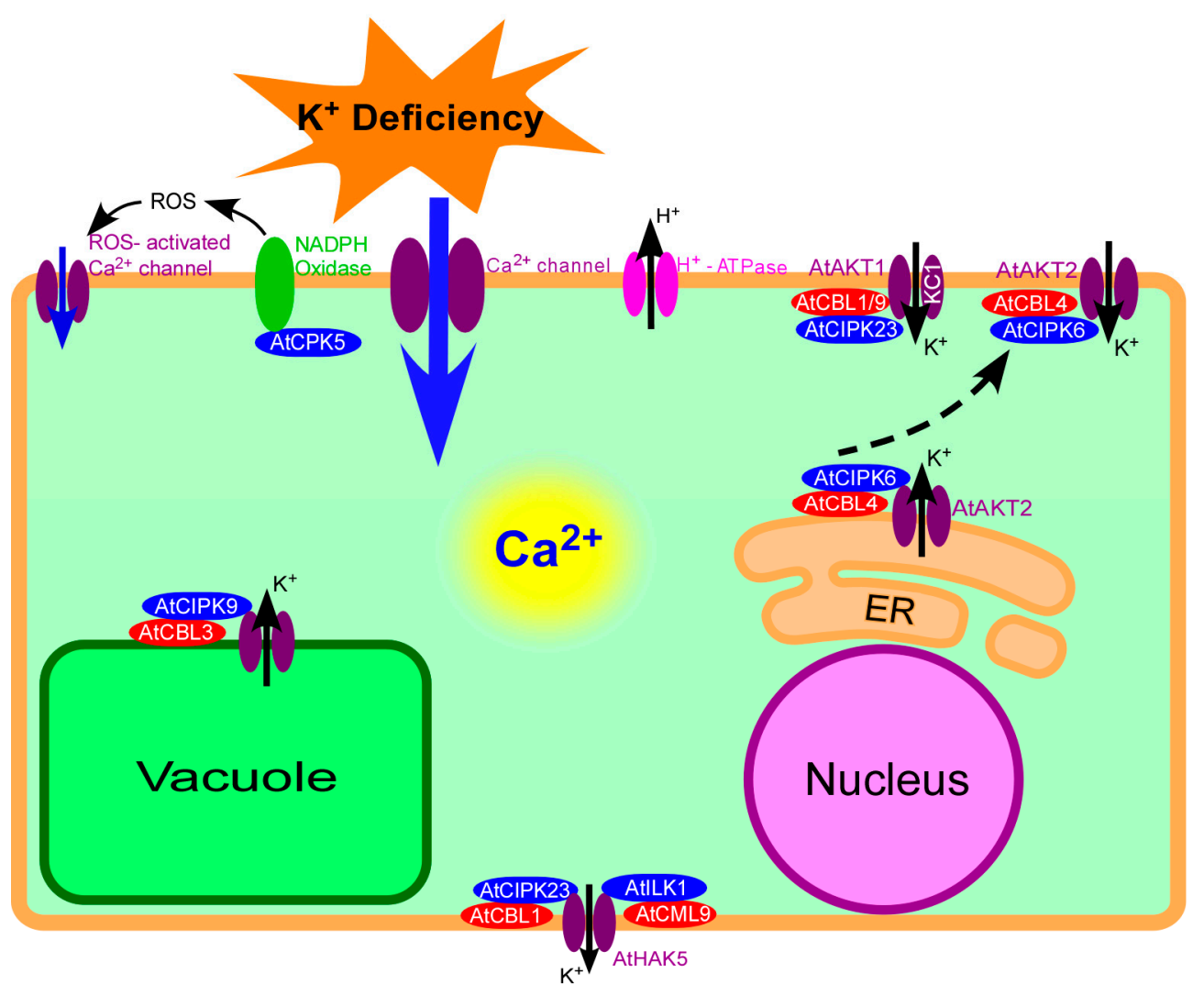

Figure 1. Calcium signaling in Arabidopsis response to $\mathrm{K}^{+}$deficiency. Plants can perceive external $\mathrm{K}^{+}$ deficiency and generate $\mathrm{K}^{+}$deficiency signals in plant cells. The signal $\mathrm{Ca}^{2+}$ can be transduced in cytosol, and eventually regulate the downstream targets at the transcriptional and posttranslational levels. ER: Endoplasmic Reticulum.

\section{Molecular Mechanisms of Calcium Signaling Involved in Plant Responses to $\mathrm{K}^{+}$Deficiency}

\subsection{Generation of Calcium in Response to $\mathrm{K}^{+}$Deficiency}

The concentration and distribution of cytosolic free calcium form the basis of calcium signaling. Under normal conditions, levels of cytosolic free calcium are low, but some organelles, including the vacuole, endoplasmic reticulum, mitochondria and so on, contain high concentrations of calcium, henceforth referred to as the calcium pool. Elevations in intracellular calcium $\left[\mathrm{Ca}^{2+}\right]_{i}$ have been recorded in the responses of both lower and higher plants to a wide variety of both biotic and abiotic stimuli $[18,19]$. In plants, $\left[\mathrm{Ca}^{2+}\right]_{\mathrm{i}}$ levels that are altered in response to multiple abiotic stresses result in calcium signatures that exhibit temporal and spatial features [20-22]. These calcium signatures can take the form of single calcium transients [23,24], oscillations [25-27], or repeated spikes [28,29]. Alterations to cytosolic calcium signals can be perceived by calcium sensors, which can result in a series of downstream responses, such as protein modification and transcriptional regulation [30-38]. Calcium sensors in Arabidopsis root are involved in both $\mathrm{K}^{+}$uptake and responses to $\mathrm{K}^{+}$deficiency. Low $\mathrm{K}^{+}$ induces $\left[\mathrm{Ca}^{2+}\right]$ to increase in Arabidopsis guard cells [39] and in the pollen tubes [40]. The results of a recent study revealed that $\mathrm{K}^{+}$deficiency triggers two successive but distinct calcium signals in roots, and that those two signals exhibit spatial and temporal specificity [16]. Calcium flows into or out of the cytoplasm via calcium channels located within the plasma membrane and endomembrane system [18,41,42]. Most calcium channels are nonselective for ions [41,43]. In plants, these calcium channels mainly include nonspecific cation channels located within the cell membrane [43,44], including members of the cyclic nucleotide-gated channel (CNGC) family [26,45-47] and the glutamate receptor channel (GLR) family [48-50], hyperosmolality-gated calcium-permeable channels [51,52], and annexins proteins [53], 
and mechanosensitive channels (MCAs) [54], as well as two-pore calcium channels (TPCs) [55,56] located in the vacuolar membrane. However, the mechanisms of their action remain unclear.

\subsection{Initial Sensing of $K^{+}$Deficiency by Calcium Channels}

In plants, although some calcium channel activation occurs via depolarization [57-59], most channels operate at highly-negative membrane voltages, and are often described as hyperpolarization-activated calcium channels (HACCs) [41,53,60-63]. After low- $\mathrm{K}^{+}$stress, calcium channels located within the root epidermis and root hair zone can be activated by hyperpolarization of the PM $[60,64]$. Calcium increases in the cytosol can activate additional calcium channels located within the inner membrane, thereby causing the calcium pool to release calcium. For instance, two-pore channel 1 (TPC1), which is a voltage-gated channel and is located within the vacuolar membrane, is involved in the influx of calcium to the cytoplasm from the vacuole [55]. In addition, the low- $\mathrm{K}^{+}$-inducing $\left[\mathrm{Ca}^{2+}\right]_{\mathrm{i}}$ increase is also mediated by ROS-activated calcium channels in the PM [61]. ROS are important signaling molecules that mediate many physiological stimuli and lead to the generation of $\left[\mathrm{Ca}^{2+}\right]_{i}$ signals under stress $[65,66]$; increases in ROS are induced by $\mathrm{K}^{+}$deficiency $[67,68]$. Elevated $\left[\mathrm{Ca}^{2+}\right]_{\mathrm{i}}$ can induce NADPH oxidase-mediated production of ROS, which in turn activates calcium-permeable ion channels, thereby resulting in further calcium influx [62,69]. Additionally, ROS have been also suggested to participate in long distance signaling with calcium, and are likely involved in generating calcium waves [70-73].

\subsection{Calcium Sensors Involved in the Sensing of $\mathrm{K}^{+}$Deprivation}

How plant cells sense transient increases in $\left[\mathrm{Ca}^{2+}\right]_{\mathrm{i}}$ in response to low- $\mathrm{K}^{+}$stress is ambiguous. Calcium signals are likely perceived by calcium sensors, decoded, and further transduced. Different calcium sensors must exist in the cytoplasm of plant cells so that different calcium signals can be recognized. In higher plants, putative calcium sensors include CaM, CML, CBL, and CDPK, which are derived mainly from four gene families [18,74-77] and which are collectively encoded by approximately 100 genes in the Arabidopsis genome [30]. Calcium sensors can be divided into two types: sensor responders and sensor relays. Sensor responders, such as CDPK, usually undergo a calcium-induced conformational change that alters the protein's own structure and activity. On the other hand, sensor relays, such as CaM, CML, and CBL, lack responder domains; these sensors first combine with calcium and subsequently undergo a conformational change that is relayed to an interacting partner. The interacting partner then responds with some change in its enzyme activity or structure. The two types of calcium sensors differ by their action: sensor responders function via intramolecular interactions (e.g., CDPK), whereas sensor relays function via biomolecular interactions (e.g., CBL interact with CIPK) $[78,79]$.

Calcium sensor responders mainly consist of CDPKs. CDPKs, which are a class of calcium-dependent protein kinases first discovered in plants, are serine/threonine protein kinases, and are probably the best-studied protein kinases involved in signal transduction in plants $[76,77,80]$. CDPKs are monomeric proteins with a molecular mass of 40 to $90 \mathrm{kDa}$, and consist of five domains: an $\mathrm{N}$-terminal variable domain, a protein kinase catalytic domain, an autoinhibitory domain, a regulatory domain, and a C-terminal domain of variable length [75-77]. The autoinhibitory domain contains a pseudo-substrate sequence that can interact with the active site and inhibit its activity. Once a calcium signal is generated, the autoinhibition of CDPKs is relieved; therefore, the CDPKs become activated, and the activated CDPKs can subsequently phosphorylate target enzymes or molecules, leading to physiological responses [81-83]. In addition to CDPKs, $\mathrm{Ca}^{2+} / \mathrm{CaM}$-regulated kinases and chimeric $\mathrm{Ca}^{2+}$ and $\mathrm{Ca}^{2+} / \mathrm{CaM}$ regulated kinases (CCaMKs) are also members of this family of $\mathrm{Ca}^{2+}$-regulated protein kinases [30]. CPK10 is involved in the $\mathrm{Ca}^{2+}$-dependent inhibition of $\mathrm{K}^{+}$in channels in guard cells [84]. Together, CPK11 and CPK24 mediate $\mathrm{Ca}^{2+}$-dependent inhibition of the activity of shaker pollen inward $\mathrm{K}^{+}$channels (SPIK/AKT6) in pollen tubes, further increasing our understanding of the CDPK-mediated regulatory mechanisms of $\mathrm{K}^{+}$channels [40]. CPK13 specifically inhibits guard 
cell-expressed KAT2 and KAT1 shaker $\mathrm{K}^{+}$channels [85]. The results of a recent study [86] showed that two CDPKs are up-regulated in tobacco seedlings under low- $\mathrm{K}^{+}$stress, whereas OsCPK9 and OsCCaMK1 are down-regulated in rice root responses to $\mathrm{K}^{+}$deficiency [87].

Calcium sensor relays mainly consist of CaMs and CML [88]; CaM is an important member of this class of calcium sensor proteins. Plant CaMs are small, acidic proteins with a molecular weight ranging from $16.7-16.8 \mathrm{kDa}$; CaM contains 4 EF-hand repeated domains that bind 4 individual $\mathrm{Ca}^{2+}$ ions. In addition, the four binding sites display cooperativity in $\mathrm{Ca}^{2+}$ binding; as such, unbound $\mathrm{CaM}$ is fully opened $[89,90]$. CaM binding with $\mathrm{Ca}^{2+}$ leads to a conformational change. This change exposes the hydrophobic surface of $\mathrm{CaM}$, which helps to interact with target proteins in a $\mathrm{Ca}^{2+}$-dependent manner, altering their activities. CaM binding with $\mathrm{Ca}^{2+}$ forms an activated $\mathrm{Ca}^{2+}-\mathrm{CaM}$ complex, and the binding of this complex to target enzymes leads to their activation [91,92]. CaM has no catalytic activity of its own, but upon binding with $\mathrm{Ca}^{2+}, \mathrm{CAM}$ modulates the activities of several enzymes and non-enzymic proteins involved in a variety of cellular processes [93-95]. CML also acts in signaling 'cross-talk' and is involved in the co-ordination of plant responses to biotic and abiotic stresses $[21,96,97]$. CML25 is an important transducer involved in the $\mathrm{Ca}^{2+}$ ions-mediated regulation of $\mathrm{K}^{+}$influx [98]. Ma et al. (2012) [87] reported that the expression levels of the calcium sensor protein genes OsCML1, OsCML18, OsCML20, and OsCML31 are up-regulated in rice under low- $\mathrm{K}^{+}$stress. Several genes that code for members of CML families are differentially expressed in tobacco seedlings under low-K $\mathrm{K}^{+}$stress [99]. In addition, a Raf-like MAPKK kinase (AtILK1) directly interacts with AtHAK5 in conjunction with the AtCML9, promoting AtHAK5 accumulation on the membrane [100]. These results indicate that calcium sensor proteins may play vital roles in connecting calcium signaling and downstream target proteins during plant responses to $\mathrm{K}^{+}$deficiency.

Another important member of the calcium sensor relays is CBL, which, like CaM and CML, has been shown to lack responder domains [101]. CBLs and CBL-interacting protein kinases (CIPKs) often form the CBL/CIPK complexes, perceiving calcium signals and relaying the signals to downstream responses in plants under low- $\mathrm{K}^{+}$stress [31-35,37,102-105].

\section{Role of the CBL/CIPK Complex in Response to $\mathrm{K}^{+}$Deficiency}

\subsection{CBL Proteins}

CBL proteins, which are involved in the salt-overly-sensitive (SOS) pathway of salt stress signal transduction, were first identified in Arabidopsis [101]. CBL proteins in plants share significant sequence similarities with the calcineurin $B$ subunit in yeast and the neuronal calcium sensors in animals [74,101,106]. In Arabidopsis, CBLs are encoded by at least 10 members of a multigene family [106-108]. Each CBL protein harbors four EF-hand motifs that facilitate $\mathrm{Ca}^{2+}$ binding; in all CBL proteins, these motifs are arranged in fixed spacing. Therefore, the weights of CBLs are nearly equal (23-26 kD); the N-terminal and C-terminal domains account for the differences in CBL weights. Unlike in other species, in Arabidopsis, the first CBL EF-hand domain consists of an unconventional 14 amino acids, not 12 amino acids; this Arabidopsis CBL EF-hand domain likely lacks the normal amino acid numbers required for $\mathrm{Ca}^{2+}$ binding $[107,109]$. The crystal structures of AtCBL2 and AtCBL4 indicate that two calcium ions are coordinated in the first and fourth EF-hand motifs despite the presence of two additional amino acids $[110,111]$. Sequence variations in EF-hand motifs most likely control the overall $\mathrm{Ca}^{2+}$-binding affinity of individual CBL proteins. This phenomenon may explain why plants can decode different calcium signals [109,112-116].

With the exception of CBL10, whose hydrophobic N-terminal region is a special transmembrane domain, other CBLs can be classified into one of two categories based on variations in their $\mathrm{N}$-terminal domain. The first category represents CBL proteins with a short $\mathrm{N}$-terminal region, which consist of 27-32 amino acids. Examples in this category include CBL1, CBL4, CBL5, CBL8, and CBL9; other CBL proteins, with exception of CBL8, all have a MGXXX(S/T) consensus sequence for $\mathrm{N}$-myristoylation [117]. The second category represents CBL proteins with an extended N-terminal 
region, which consist of 41-43 amino acids. Examples in this category include CBL2, CBL3, and CBL6, which lack recognizable lipid modifications [117]. Sequence comparisons place CBL7 within this category; therefore, the CBL7 protein appears to have lost its N-terminal extension during evolution [106,112].

CBL proteins were first identified in model plant Arabidopsis [74,101]; subsequent bioinformatics analysis has revealed that these kinds of proteins also exist in other species. The Oryza sativa (rice) genome contains 10 genes that encode CBL proteins [108], and the Populus trichocarpa (poplar) genome also contains 10 genes that encode CBL proteins [118]. The fully-sequenced genomes of the dicotyledonous plant Vitis vinifera (grape) and the monocotyledonous plant Sorghum bicolor (sorghum) have been analyzed in attempt to detect the presence of CBLs; these analyses revealed 8 CBLs in grape and 6 CBLs in sorghum [112]. Gossipium raimondii (cotton) was found to contain the highest number of CBL genes (13) among the 38 plant species analyzed [119]. And 19 members of the BrrCBL genes were identified in Brassica rapa var. rapa (turnip) [120]. A comparative analysis of CBLs from all these species further supports the classification of these proteins according to their N-terminal domain [112]. An analysis of the genomic sequences of algae and nonvascular plants revealed that the genome of the moss Physcomitrella patens encodes 4 CBL proteins, and that the genome of the fern Selaginella moellendorffii also encodes 4 CBL proteins. In addition, one CBL protein was identified in the green alga Chlorella sp., as well as in the genome of the smallest known free-living eukaryotic alga, Ostreococcus tauri [121]. In general, these studies of lower plants have enabled us to address the general evolutionary aspects of this signaling network [112].

\subsection{CBL-Interacting Protein Kinases (CIPKs)}

Protein kinases that specifically interact with CBL proteins have been identified; these kinases are referred to as CIPKs, which were mentioned earlier with salt-overly-sensitive 2 (SOS2), SOS3-interacting proteins (SIPs), and protein kinase S (PKS) [122-124]. All of these CIPKs share a typical two-domain structure comprising an $\mathrm{N}$-terminal kinase domain and a C-terminal catalytic domain, which are separated by a junction domain [109,112]. Sucrose non-fermenting 1 (SNF1)-related protein kinases (SnRKs) are important kinases in plants, and exhibit high sequence homology to metabolic regulators found in mammals (5'-AMP-activated protein kinases [AMPKs]) and in yeast (SNF1); the three combined kinases form the protein kinase superfamily. Amino acid sequence identification and expression pattern analyses have revealed that the SnRK family of protein kinases can be categorized into three classes: SnRK1, SnRK2, and SnRK3 [125-127]. Arabidopsis CIPKs constitute a kind of serine-threonine kinase, and have a highly-conserved N-terminal catalytic domain; these proteins have been classified as SnRK3s [125,128].

The N-terminal domain of a protein kinase contains a conserved activation loop. Assays of mutants revealed that the Thr168, Ser156, or Tyr175 to Asp change in the activation loop of CIPK24/SOS2 protein kinase [129-131], the Thr178 to Asp change in the activation loop of CIPK9/PKS6 [132], the Thr161 to Asp change in the activation loop of CIPK8/PKS11 [133], and the Thr183 to Asp change in the activation loop of CIPK3 [134] can cause strong activation of CIPK protein kinases, even in the absence of $\mathrm{Ca}^{2+}$ or CBLs. Thus, these several conserved amino acid residues may be phosphorylation sites of CIPK protein kinases, whose phosphorylation results in the activation of CIPK [112]. Furthermore, an additional phosphorylation site (Ser 228) has been identified as a target of autophosphorylation activity in the C-terminal region of the CIPK24/SOS2 kinase domain [135].

Within the otherwise divergent $C$-terminal regulatory domain, CIPKs have a conserved domain, a NAF motif, and a 24-aminoacid domain with the conserved amino acids $\mathrm{N}, \mathrm{A}$, and $\mathrm{F}$ that are required for the CBL-CIPK interactions; the NAF motif is also referred to as a FISL motif because of the complete conservation of the six amino acid residues A, F, I, S, L, and F. The NAF/FISL motif of CIPKs is sufficient for mediating protein interactions with all CBL proteins $[128,129,136,137]$. The NAF/FISL motif is also necessary and sufficient for keeping CIPKs inactive, and serves as an autoinhibitory domain; removal of the NAF/FISL domain can increase the activity of CIPKs [129,132]. 
Another important functional domain is the protein phosphatase interaction (PPI) motif in the C-terminal region of CIPKs; this motif is adjacent to the NAF/FISL motif. The PPI motif consists of 37 amino acid residues, and was first identified in CIPK24/SOS2, which is necessary and sufficient for interaction with ABA-INSENSITIVE 2 (ABI2) [138]. The PPI motif is conserved in CIPK protein kinases; all of these motifs interact with 2C-type protein phosphatase (PP2C) $[34,128,138,139]$. In plants, $\mathrm{PP} 2 \mathrm{C}$ is a strong negative regulator of the stress-activated, mitogen-activated protein kinase (MAPK) pathway, which is involved in plant responses to abiotic stresses and growth regulation [140-142]. PP2C interaction with CIPK results in the complete replacement of the combination between CBL proteins and the NAF domain or a portion of the PPI domain of CIPKs [112]. The dissociation of CBL proteins from the NAF domain of CIPK prevents the autophosphorylation of CIPK, thereby transforming the kinase into an inactive state $[129,132]$.

\subsection{Involvement of the CBL/CIPK Complex in the Sensing of $\mathrm{K}^{+}$Deficiency}

Some CBL protein family members that interact with CIPKs function in plant responses to $\mathrm{K}^{+}$ deficiency (Figure 2) [31-35,37,102-105]. The first CBL proteins identified to be involved in the $\mathrm{K}^{+}$ deficiency response were the PM-localized calcium sensors CBL1 and CBL9; these sensors interact with the cytoplasm-localized Ser/Thr kinase CIPK23, and recruit it to the root cell PM, where the complex subsequently phosphorylates AKT1 [31,102,143]. AKT1, a shaker inward $\mathrm{K}^{+}$channel [144-146], is considered a major component involved in $\mathrm{K}^{+}$uptake in Arabidopsis root cells under low- $\mathrm{K}^{+}$ conditions [147-149]. In addition, AtKC1, a $\mathrm{K}^{+}$channel regulatory subunit that negatively modulates many inward $\mathrm{K}^{+}$channels, interacts with AtAKT1, forming an AtAKT1-AtKC1 heteromeric channel, and modulates AtAKT1 activity together with AtCIPK23, to synergistically regulate AtAKT1-mediated low- $\mathrm{K}^{+}$stress responses $[150,151]$. Another CBL protein, CBL10, was recently shown to be a negative regulator of the AKT1 channel. CBL10 may compete with CIPK23 for binding to AKT1, and CBL10 interacts directly with the AKT1 channel and inhibits AKT1-mediated $\mathrm{K}^{+}$flux into the cytoplasm. In Arabidopsis, this inhibition ultimately maintains $\mathrm{K}^{+}$homeostasis under ion stress conditions in a CIPK-independent manner [35]. The calcium sensor CBL4, together with the interacting protein kinase CIPK6, modulates the activity and PM targeting of the $\mathrm{K}^{+}$channel AKT2 in Arabidopsis; CBL4 in conjunction with CIPK6 mediates the translocation of AKT2 from the endoplasmic reticulum membrane to the PM in a kinase-interaction-dependent but phosphorylation-independent manner in plant cells, and enhances AKT2 activity in oocytes [33]. AKT2 is unique among the nine shaker-type $\mathrm{K}^{+}$channel subunits expressed in Arabidopsis, because AKT2 exhibits weak inward-rectifying activity in oocytes [152,153]; several studies have suggested that this channel is regulated by unknown protein kinases and by the protein phosphatase PP2CA [154-156]. A recent study demonstrated that CBL3 and CIPK9 work together and function in $\mathrm{K}^{+}$homeostasis under low- $\mathrm{K}^{+}$stress; this complex mediates the regulation of putative tonoplast-localized outward $\mathrm{K}^{+}$channels [104]. CIPK9 is the CIPK family member which is most similar to CIPK23, and CIPK9 loss of function results in a phenotype that is tolerant to $\mathrm{K}^{+}$deficiency conditions [31]; in contrast, CIPK9 overexpression lines are sensitive to $\mathrm{K}^{+}$deficiency stress. Furthermore, because $\mathrm{K}^{+}$deficiency symptoms first appear in relatively old leaves, CIPK9 may be involved in $\mathrm{K}^{+}$reallocation from older leaves to the younger leaves during $\mathrm{K}^{+}$ deficiency [32,157]. In addition, the AtCBL1/AtCIPK23 complex can phosphorylate AtHAK5, which is a KT/KUP/HAK-type transporter whose expression occurs mainly in the roots [37]. The transcription of HAK5 is induced by $\mathrm{K}^{+}$deficiency via the transcription factor RAP2.11 [147,158], which is considered to function predominantly in the uptake of $\mathrm{K}^{+}$from the soil [37,145,147,159-161].

These CBLs-CIPKs-AKT1/AKT2/HAK5 pathways are important mechanisms in the response to low- $\mathrm{K}^{+}$stress in Arabidopsis. Similar mechanisms have also been identified in other plant species. The OsCBL1-OsCIPK23-OsAKT1 pathway was identified in rice [36]. Rice OsCIPKs show high amino acid sequence similarity to Arabidopsis CIPKs; eight OsCIPK genes (OsCIPK2, 6, 9, 10, 14, 15, 23, and 26) are upregulated under low- $\mathrm{K}^{+}$stress, whereas two OsCIPK genes (OsCIPK29 and 31) are down-regulated [108]. Another study demonstrated that the AtCBL9/AtCIPK23 kinase complex 
activates DmKT1, which has been identified as a $\mathrm{K}^{+}$-selective channel of voltage-dependent high capacity and low affinity; the first proton-driven high-affinity $\mathrm{K}^{+}$transporter with weak selectivity (DmHAK5) is also activated by the same kinase complex [38].

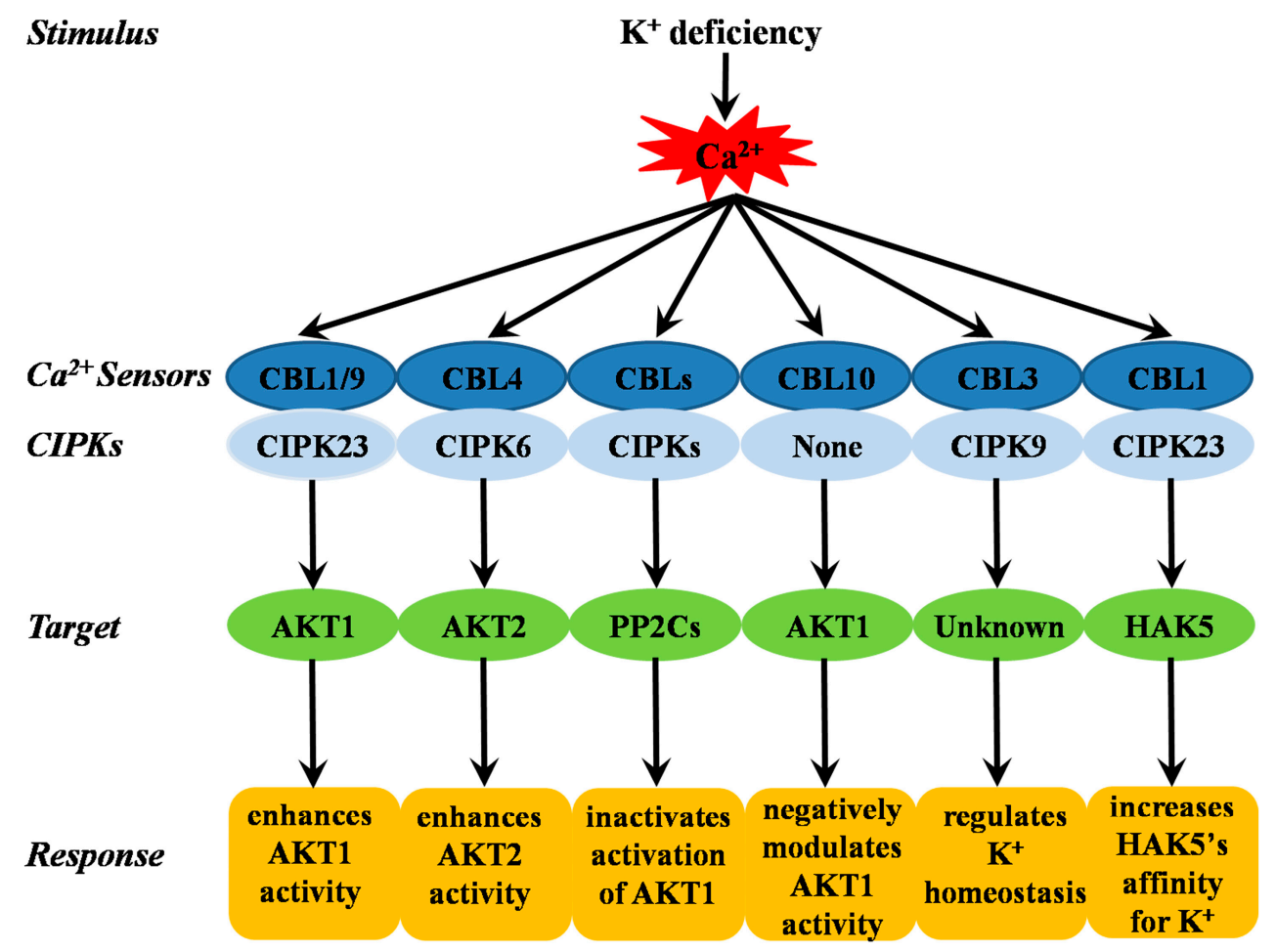

Figure 2. The summary of CBL-CIPK complex involved in response to $\mathrm{K}^{+}$deficiency.

Furthermore, CBL/CIPK (CIPK6, CIPK16, and CIPK23) complexes can interact with the AKT1-interacting PP2CA (AIP1) and AIP1 homologue (AIP1H), both of which are protein phosphatase PP2Cs, via the direct binding of the kinase domain of CIPKs to indirectly deactivate AKT1 by inhibiting phosphorylation. Several CBLs have been reported to interact with and inhibit the activity of PP2Cs, thereby enhancing CIPK-induced AKT1 activation; this phenomenon forms a kinase/phosphatase partnership that enables AKT1 activity to be switched on and off [34,103]. In addition, AtPP2CA can interact physically and functionally with AKT2, and can inhibit AKT2-mediated $\mathrm{K}^{+}$currents via the direct phosphorylation of AKT2 [154].

\section{Conclusions and Perspectives}

$\mathrm{K}^{+}$is an essential macronutrient and is associated with or involved in several physiological processes supporting plant growth and development, such as photosynthesis, enzyme activation, osmoregulation, electrical neutralization, $\mathrm{pH}$ and ion homeostasis, anion-cation balance, membrane electrical potential, protein and starch synthesis, sugar and nutrient transport, and stomatal movements. $\mathrm{K}^{+}$deprivation leads to a strong increase in chlorophyll degradation. Various $\mathrm{K}^{+}$shortage-activated signaling cascades exist; these cascades involve ROS, phytohormones, calcium, and phosphatidic acid. Among these signaling cascades, calcium signaling is the most important signaling system in plant cells. Thus far, our knowledge on the molecular mechanisms of calcium signaling in plant responses to $\mathrm{K}^{+}$deficiency is still limited.

Calcium plays a critical role in plant responses to low $-\mathrm{K}^{+}$stress. Although tremendous progress has been made in understanding plant responses to low- $\mathrm{K}^{+}$stress, one important question that remains unanswered is how calcium as a messenger can relay information that distinguishes different extracellular signals, triggering different processes and specific responses in cells. The results of the previous studies suggest that $\mathrm{K}^{+}$deficiency can induce changes in intracellular calcium levels that 
exhibit temporal and spatial features. The decoding of calcium signatures in plant cells might depend largely on the presence of various calcium sensors, including CaM, CML, CDPK, and CBL, as well as their targets. In particular, the CBL-CIPK signaling system is a central and critical signaling system for decoding calcium signatures and for translating those calcium signatures into downstream responses to $\mathrm{K}^{+}$deficiency.

Over the last two decades, the extensive genomic, genetic, and molecular physiological studies have begun to shed light on the transport regulation and signaling mechanisms of plant responses to $\mathrm{K}^{+}$deficiency. Further identification of important calcium signaling components involved in plant responses to $\mathrm{K}^{+}$deficiency is important. Detailed functional characterization of these calcium-signaling components is also needed to elucidate the complex network of plant signaling in response to $\mathrm{K}^{+}$ deficiency. Even though many $\mathrm{K}^{+}$transporters and channels in higher plants have been functionally characterized, specific $\mathrm{K}^{+}$sensors remain unknown. Thus, future investigations should give attention to further functional characterization of $\mathrm{K}^{+}$sensors and to the regulatory mechanisms of these sensors. Given that $\mathrm{K}^{+}$deficiency could induce $\left[\mathrm{Ca}^{2+}\right]_{\mathrm{i}}$ to increase in Arabidopsis guard cells and in the pollen tubes or triggers calcium signals in Arabidopsis roots, the perception-defective of $\mathrm{K}^{+}$deficiency mutants are likely to be screened via detection of the plant calcium signal.

Funding: This work was funded by China Postdoctoral Science Foundation, grant number (2018M633109).

Acknowledgments: We thank Zhen-Ming Pei, Zhangli Hu, two anonymous reviewers and the Editor for their valuable comments on the manuscript.

Conflicts of Interest: The authors declare no conflict of interest.

\section{References}

1. Leigh, R.A.; Wyn Jones, R.G. A hypothesis relating critical potassium concentrations for growth to the distribution and functions of this ion in the plant cell. New Phytol. 1984, 97, 1-13. [CrossRef]

2. Demidchik, V. Mechanisms and physiological roles of $\mathrm{K}^{+}$efflux from root cells. J. Plant Physiol. 2014, 171, 696-707. [CrossRef] [PubMed]

3. Zörb, C.; Senbayram, M.; Peiter, E. Potassium in agriculture - status and perspectives. J. Plant Physiol. 2014, 171, 656-669. [CrossRef] [PubMed]

4. Shabala, S. Signalling by potassium: Another second messenger to add to the list? J. Exp. Bot. 2017, 68, 4003-4007. [CrossRef] [PubMed]

5. Jungk, A.; Claassen, N. Availability of phosphate and potassium as the result of interactions between root and soil in the rhizosphere. J. Plant Nutr. Soil Sci. 1986, 149, 411-427. [CrossRef]

6. Reddy, K.R.; Zhao, D. Interactive effects of elevated $\mathrm{CO}_{2}$ and potassium deficiency on photosynthesis, growth, and biomass partitioning of cotton. Field Crops Res. 2005, 94, 201-213. [CrossRef]

7. Hafsi, C.; Falleh, H.; Saada, M.; Ksouri, R.; Abdelly, C. Potassium deficiency alters growth, photosynthetic performance, secondary metabolites content, and related antioxidant capacity in sulla carnosa grown under moderate salinity. Plant Physiol. Biochem. 2017, 118, 609-617. [CrossRef] [PubMed]

8. Hu, W.; Lv, X.; Yang, J.; Chen, B.; Zhao, W.; Meng, Y.; Wang, Y.; Zhou, Z.; Oosterhuis, D.M. Effects of potassium deficiency on antioxidant metabolism related to leaf senescence in cotton (Gossypium hirsutum L.). Field Crops Res. 2016, 191, 139-149. [CrossRef]

9. Jordan-Meille, L.; Pellerin, S. Leaf area establishment of a maize (Zea Mays L.) field crop under potassium deficiency. Plant Soil 2004, 265, 75-92. [CrossRef]

10. Singh, S.K.; Reddy, V.R. Potassium starvation limits soybean growth more than the photosynthetic processes across co2 levels. Front. Plant Sci. 2017, 8, 991. [CrossRef] [PubMed]

11. Desbrosses, G.; Josefsson, C.; Rigas, S.; Hatzopoulos, P.; Dolan, L. Akt1 and trh1 are required during root hair elongation in arabidopsis. J. Exp. Bot. 2003, 54, 781-788. [CrossRef] [PubMed]

12. Chen, G.; Feng, H.; Hu, Q.; Qu, H.; Chen, A.; Yu, L.; Xu, G. Improving rice tolerance to potassium deficiency by enhancing oshak16p:Wox11-controlled root development. Plant Biotechnol. J. 2015, 13, 833-848. [CrossRef] [PubMed] 
13. Kim, M.J.; Ciani, S.; Schachtman, D.P. A peroxidase contributes to ros production during arabidopsis root response to potassium deficiency. Mol. Plant 2010, 3, 420-427. [CrossRef] [PubMed]

14. Wang, Y.; Li, B.; Du, M.; Eneji, A.E.; Wang, B.; Duan, L.; Li, Z.; Tian, X. Mechanism of phytohormone involvement in feedback regulation of cotton leaf senescence induced by potassium deficiency. J. Exp. Bot. 2012, 63, 5887-5901. [CrossRef] [PubMed]

15. Schachtman, D.P. The role of ethylene in plant responses to $\mathrm{K}^{+}$deficiency. Front. Plant Sci. 2015, 6, 1153. [CrossRef] [PubMed]

16. Behera, S.; Long, Y.; Schmitz-Thom, I.; Wang, X.P.; Zhang, C.; Li, H.; Steinhorst, L.; Manishankar, P.; Ren, X.L.; Offenborn, J.N.; et al. Two spatially and temporally distinct ca2+ signals convey arabidopsis thaliana responses to $\mathrm{K}^{+}$deficiency. New Phytol. 2017, 213, 739-750. [CrossRef] [PubMed]

17. Singh, A.; Bhatnagar, N.; Pandey, A.; Pandey, G.K. Plant phospholipase c family: Regulation and functional role in lipid signaling. Cell Calcium 2015, 58, 139-146. [CrossRef] [PubMed]

18. White, P.J.; Broadley, M.R. Calcium in plants. Anna. Bot. 2003, 92, 487-511. [CrossRef] [PubMed]

19. Bose, J.; Pottosin, I.I.; Shabala, S.S.; Palmgren, M.G.; Shabala, S. Calcium efflux systems in stress signaling and adaptation in plants. Front. Plant Sci. 2011, 2, 85. [CrossRef] [PubMed]

20. Scrase-Field, S.A.M.G.; Knight, M.R. Calcium: Just a chemical switch? Curr. Opin. Plant Biol. 2003, 6, 500-506. [CrossRef]

21. Ranty, B.; Aldon, D.; Cotelle, V.; Galaud, J.P.; Thuleau, P.; Mazars, C. Calcium sensors as key hubs in plant responses to biotic and abiotic stresses. Front. Plant Sci. 2016, 7, 327. [CrossRef] [PubMed]

22. Cao, X.Q.; Jiang, Z.H.; Yi, Y.Y.; Yang, Y.; Ke, L.P.; Pei, Z.M.; Zhu, S. Biotic and abiotic stresses activate different $\mathrm{ca}(2+)$ permeable channels in arabidopsis. Front. Plant Sci. 2017, 8, 83. [CrossRef] [PubMed]

23. Knight, H.; Trewavas, A.J.; Knight, M.R. Cold calcium signaling in arabidopsis involves two cellular pools and a change in calcium signature after acclimation. Plant Cell 1996, 8, 489-503. [CrossRef] [PubMed]

24. Navazio, L.; Moscatiello, R.; Genre, A.; Novero, M.; Baldan, B.; Bonfante, P.; Mariani, P. A diffusible signal from arbuscular mycorrhizal fungi elicits a transient cytosolic calcium elevation in host plant cells. Plant Physiol. 2007, 144, 673-681. [CrossRef] [PubMed]

25. McAinsh, M.R.; Webb, A.A.R.; Taylor, J.E.; Hetherington, A.M. Stimulus-induced oscillations in guard cell cytosolic free calcium. Plant Cell 1995, 7, 1207-1219. [CrossRef] [PubMed]

26. Charpentier, M.; Sun, J.; Vaz, M.T.; Radhakrishnan, G.V.; Findlay, K.; Soumpourou, E.; Thouin, J.; Véry, A.A.; Sanders, D.; Morris, R.J. Nuclear-localized cyclic nucleotide-gated channels mediate symbiotic calcium oscillations. Science 2016, 352, 1102. [CrossRef] [PubMed]

27. Candeo, A.; Doccula, F.G.; Valentini, G.; Bassi, A.; Costa, A. Light sheet fluorescence microscopy quantifies calcium oscillations in root hairs of arabidopsis thaliana. Plant Cell Physiol. 2017, 58, 1161-1172. [CrossRef] [PubMed]

28. Sciacca, E.; Spinella, S.; Genre, A.; Calcagno, C. Analysis of calcium spiking in plant root epidermis through cwc modeling. Electron. Notes Theor. Comput. Sci. 2011, 277, 65-76. [CrossRef]

29. Downie, J.A. Calcium signals in plant immunity: A spiky issue. New Phytol. 2014, 204, 733-735. [CrossRef] [PubMed]

30. Bouché, N.; Yellin, A.; Snedden, W.A.; Fromm, H. Plant-specific calmodulin-binding proteins. Annu. Rev. Plant Biol. 2005, 56, 435-466. [CrossRef] [PubMed]

31. Xu, J.; Li, H.D.; Chen, L.Q.; Wang, Y.; Liu, L.L.; He, L.; Wu, W.H. A protein kinase, interacting with two calcineurin b-like proteins, regulates $\mathrm{K}^{+}$transporter akt1 in arabidopsis. Cell 2006, 125, 1347-1360. [CrossRef] [PubMed]

32. Pandey, G.K.; Cheong, Y.H.; Kim, B.G.; Grant, J.J.; Li, L.; Luan, S. Cipk9: A calcium sensor-interacting protein kinase required for low-potassium tolerance in arabidopsis. Cell Res. 2007, 17, 411-421. [CrossRef] [PubMed]

33. Held, K.; Pascaud, F.; Eckert, C.; Gajdanowicz, P.; Hashimoto, K.; Corratge-Faillie, C.; Offenborn, J.N.; Lacombe, B.; Dreyer, I.; Thibaud, J.B.; et al. Calcium-dependent modulation and plasma membrane targeting of the akt2 potassium channel by the cbl4/cipk6 calcium sensor/protein kinase complex. Cell Res. 2011, 21, 1116-1130. [CrossRef] [PubMed]

34. Lan, W.Z.; Lee, S.C.; Che, Y.F.; Jiang, Y.Q.; Luan, S. Mechanistic analysis of akt1 regulation by the cbl-cipk-pp2ca interactions. Mol. Plant 2011, 4, 527-536. [CrossRef] [PubMed] 
35. Ren, X.L.; Qi, G.N.; Feng, H.Q.; Zhao, S.; Zhao, S.S.; Wang, Y.; Wu, W.H. Calcineurin b-like protein cbl10 directly interacts with akt1 and modulates $\mathrm{K}^{+}$homeostasis in arabidopsis. Plant J. 2013, 74, 258-266. [CrossRef] [PubMed]

36. Li, J.; Long, Y.; Qi, G.N.; Li, J.; Xu, Z.J.; Wu, W.H.; Wang, Y. The os-akt1 channel is critical for $\mathrm{K}^{+}$uptake in rice roots and is modulated by the rice cbl1-cipk23 complex. Plant Cell 2014, 26, 3387-3402. [CrossRef] [PubMed]

37. Ragel, P.; Rodenas, R.; Garcia-Martin, E.; Andres, Z.; Villalta, I.; Nieves-Cordones, M.; Rivero, R.M.; Martinez, V.; Pardo, J.M.; Quintero, F.J.; et al. The cbl-interacting protein kinase cipk23 regulates hak5-mediated high-affinity $\mathrm{K}^{+}$uptake in arabidopsis roots. Plant Physiol. 2015, 169, 2863-2873. [PubMed]

38. Scherzer, S.; Bohm, J.; Krol, E.; Shabala, L.; Kreuzer, I.; Larisch, C.; Bemm, F.; Al-Rasheid, K.A.; Shabala, S.; Rennenberg, H.; et al. Calcium sensor kinase activates potassium uptake systems in gland cells of venus flytraps. Proc. Natl. Acad. Sci. USA 2015, 112, 7309-7314. [CrossRef] [PubMed]

39. Allen, G.J.; Chu, S.P.; Harrington, C.L.; Schumacher, K.; Hoffmann, T.; Tang, Y.Y.; Grill, E.; Schroeder, J.I. A defined range of guard cell calcium oscillation parameters encodes stomatal movements. Nature 2001, 411, 1053-1057. [CrossRef] [PubMed]

40. Zhao, L.N.; Shen, L.K.; Zhang, W.Z.; Zhang, W.; Wang, Y.; Wu, W.H. Ca ${ }^{2+}$-dependent protein kinase11 and 24 modulate the activity of the inward rectifying $\mathrm{K}^{+}$channels in arabidopsis pollen tubes. Plant Cell 2013, 25, 649-661. [CrossRef] [PubMed]

41. Hetherington, A.M.; Brownlee, C. The generation of $\mathrm{Ca}^{2+}$ signals in plants. Annu. Rev. Plant Biol. 2004, 55, 401-427. [CrossRef] [PubMed]

42. Ma, W.; Berkowitz, G.A. Cyclic nucleotide gated channels (cngcs) and the generation of $\mathrm{Ca}^{2+}$ signals. Signal. Commun. Plants 2011, 93-110.

43. Dodd, A.N.; Kudla, J.; Sanders, D. The language of calcium signaling. Annu. Rev. Plant Biol. 2010, 61, 593-620. [CrossRef] [PubMed]

44. Edel, K.H.; Marchadier, E.; Brownlee, C.; Kudla, J.; Hetherington, A.M. The evolution of calcium-based signalling in plants. Curr. Biol. 2017, 27, R667-R679. [CrossRef] [PubMed]

45. Gao, Q.-F.; Fei, C.-F.; Dong, J.-Y.; Gu, L.-L.; Wang, Y.-F. Arabidopsis cngc18 is a Ca ${ }^{2+}$-permeable channel. Mol. Plant 2014, 7, 739-743. [CrossRef] [PubMed]

46. Wang, Y.; Kang, Y.; Ma, C.; Miao, R.; Wu, C.; Long, Y.; Ge, T.; Wu, Z.; Hou, X.; Zhang, J.; et al. Cngc2 is a ca2+ influx channel that prevents accumulation of apoplastic $\mathrm{Ca}^{2+}$ in the leaf. Plant Physiol. 2017, 173, 1342-1354. [CrossRef] [PubMed]

47. Zhang, S.; Pan, Y.; Tian, W.; Dong, M.; Zhu, H.; Luan, S.; Li, L. Arabidopsis cngc14 mediates calcium influx required for tip growth in root hairs. Mol. Plant 2017, 10, 1004-1006. [CrossRef] [PubMed]

48. Michard, E.; Lima, P.T.; Borges, F.; Silva, A.C.; Portes, M.T.; Carvalho, J.E.; Gilliham, M.; Liu, L.-H.; Obermeyer, G.; Feijó, J.A. Glutamate receptor-like genes form $\mathrm{Ca}^{2+}$ channels in pollen tubes and are regulated by pistil d-serine. Science 2011, 332, 434-437. [CrossRef] [PubMed]

49. Mousavi, S.A.; Chauvin, A.; Pascaud, F.; Kellenberger, S.; Farmer, E.E. Glutamate receptor-like genes mediate leaf-to-leaf wound signalling. Nature 2013, 500, 422-426. [CrossRef] [PubMed]

50. Ortiz-Ramirez, C.; Michard, E.; Simon, A.A.; Damineli, D.S.C.; Hernandez-Coronado, M.; Becker, J.D.; Feijo, J.A. Glutamate receptor-like channels are essential for chemotaxis and reproduction in mosses. Nature 2017, 549, 91-95. [CrossRef] [PubMed]

51. Yuan, F.; Yang, H.; Xue, Y.; Kong, D.; Ye, R.; Li, C.; Zhang, J.; Theprungsirikul, L.; Shrift, T.; Krichilsky, B.; et al. Osca1 mediates osmotic-stress-evoked $\mathrm{Ca}^{2+}$ increases vital for osmosensing in arabidopsis. Nature 2014, 514, 367. [CrossRef] [PubMed]

52. Hou, C.; Tian, W.; Kleist, T.; He, K.; Garcia, V.; Bai, F.; Hao, Y.; Luan, S.; Li, L. Duf221 proteins are a family of osmosensitive calcium-permeable cation channels conserved across eukaryotes. Cell Res. 2014, 24, 632-635. [CrossRef] [PubMed]

53. Laohavisit, A.; Mortimer, J.C.; Demidchik, V.; Coxon, K.M.; Stancombe, M.A.; Macpherson, N.; Brownlee, C.; Hofmann, A.; Webb, A.A.R.; Miedema, H.; et al. Zea mays annexins modulate cytosolic free $\mathrm{Ca}^{2+}$ and generate a $\mathrm{Ca}^{2+}$-permeable conductance. Plant Cell 2009, 21, 479-493. [CrossRef] [PubMed]

54. Kurusu, T.; Kuchitsu, K.; Nakano, M.; Nakayama, Y.; Iida, H. Plant mechanosensing and Ca ${ }^{2+}$ transport. Trends Plant Sci. 2013, 18, 227-233. [CrossRef] [PubMed] 
55. Peiter, E.; Maathuis, F.J.M.; Mills, L.N.; Knight, H.; Pelloux, J.; Hetherington, A.M.; Sanders, D. The vacuolar $\mathrm{Ca}^{2+}$-activated channel tpc1 regulates germination and stomatal movement. Nature 2005, 434, 404-408. [CrossRef] [PubMed]

56. Morgan, A.J.; Galione, A. Two-pore channels (tpcs): Current controversies. BioEssays 2014, 36, $173-183$. [CrossRef] [PubMed]

57. Thion, L.; Mazars, C.; Nacry, P.; Bouchez, D.; Moreau, M.; Ranjeva, R.; Thuleau, P. Plasma membrane depolarization-activated calcium channels, stimulated by microtubule-depolymerizing drugs in wild-type arabidopsis thaliana protoplasts, display constitutively large activities and a longer half-life in ton 2 mutant cells affected in the organization of cortical microtubules. Plant J. 1998, 13, 603-610. [PubMed]

58. White, P.J. Depolarization-activated calcium channels shape the calcium signatures induced by low-temperature stress. New Phytol. 2009, 183, 6-8. [CrossRef] [PubMed]

59. Zhou, L.; Lan, W.; Jiang, Y.; Fang, W.; Luan, S. A calcium-dependent protein kinase interacts with and activates a calcium channel to regulate pollen tube growth. Mol. Plant 2014, 7, 369-376. [CrossRef] [PubMed]

60. Very, A.A.; Davies, J.M. Hyperpolarization-activated calcium channels at the tip of arabidopsis root hairs. Proc. Natl. Acad. Sci. USA 2000, 97, 9801-9806. [CrossRef] [PubMed]

61. Demidchik, V.; Maathuis, F.J. Physiological roles of nonselective cation channels in plants: From salt stress to signalling and development. New Phytol. 2007, 175, 387-404. [CrossRef] [PubMed]

62. Demidchik, V.; Shabala, S.N.; Davies, J.M. Spatial variation in h2o2 response of arabidopsis thaliana root epidermal $\mathrm{Ca}^{2+}$ flux and plasma membrane $\mathrm{Ca}^{2+}$ channels. Plant J. 2007, 49, 377-386. [CrossRef] [PubMed]

63. Demidchik, V.; Shabala, S. Mechanisms of cytosolic calcium elevation in plants: The role of ion channels, calcium extrusion systems and NADPH oxidase-mediated 'ros- $\mathrm{Ca}^{2+}$ hub'. Funct. Plant Biol. 2018, 45, 9. [CrossRef]

64. Demidchik, V.; Davenport, R.J.; Tester, M. Nonselective cation channels in plants. Annu. Rev. Plant Biol. 2002, 53, 67-107. [CrossRef] [PubMed]

65. Pitzschke, A.; Hirt, H. Mitogen-activated protein kinases and reactive oxygen species signaling in plants. Plant Physiol. 2006, 141, 351-356. [CrossRef] [PubMed]

66. Kurusu, T.; Kuchitsu, K.; Tada, Y. Plant signaling networks involving $\mathrm{Ca}^{2+}$ and rboh/nox-mediated ros production under salinity stress. Front. Plant Sci. 2015, 6, 427. [CrossRef] [PubMed]

67. Shin, R.; Schachtman, D.P. Hydrogen peroxide mediates plant root cell response to nutrient deprivation. Proc. Natl. Acad. Sci. USA 2004, 101, 8827-8832. [CrossRef] [PubMed]

68. Shin, R.; Berg, R.H.; Schachtman, D.P. Reactive oxygen species and root hairs in arabidopsis root response to nitrogen, phosphorus and potassium deficiency. Plant Cell Physiol. 2005, 46, 1350-1357. [CrossRef] [PubMed]

69. Pei, Z.-M.; Murata, Y.; Benning, G.; Thomine, S.; Klüsener, B.; Allen, G.J.; Grill, E.; Schroeder, J.I. Calcium channels activated by hydrogen peroxide mediate abscisic acid signalling in guard cells. Nature 2000, 406, 731. [CrossRef] [PubMed]

70. Dubiella, U.; Seybold, H.; Durian, G.; Komander, E.; Lassig, R.; Witte, C.P.; Schulze, W.X.; Romeis, T. Calcium-dependent protein kinase/NADPH oxidase activation circuit is required for rapid defense signal propagation. Proc. Natl. Acad. Sci. USA 2013, 110, 8744-8749. [CrossRef] [PubMed]

71. Choi, W.G.; Miller, G.; Wallace, I.; Harper, J.; Mittler, R.; Gilroy, S. Orchestrating rapid long-distance signaling in plants with $\mathrm{Ca}^{2+}$, ROS and electrical signals. Plant J. 2017, 90, 698-707. [CrossRef] [PubMed]

72. Evans, M.J.; Choi, W.G.; Gilroy, S.; Morris, R.J. A ros-assisted calcium wave dependent on the atrbohd NADPH oxidase and tpc1 cation channel propagates the systemic response to salt stress. Plant Physiol. 2016, 171, 1771-1784. [CrossRef] [PubMed]

73. Steinhorst, L.; Kudla, J. Calcium and reactive oxygen species rule the waves of signaling. Plant Physiol. 2013, 163, 471-485. [CrossRef] [PubMed]

74. Kudla, J.; Xu, Q.; Harter, K.; Gruissem, W.; Luan, S. Genes for calcineurin b-like proteins in arabidopsis are differentially regulated by stress signals. Proc. Natl. Acad. Sci. USA 1999, 96, 4718-4723. [CrossRef] [PubMed]

75. Harmon, A.C.; Gribskov, M.; Harper, J.F. Cdpks-A kinase for every Ca ${ }^{2+}$ signal? Trends Plant Sci. 2000, 5, 154-159. [CrossRef]

76. Harmon, A.C.; Gribskov, M.; Gubrium, E.; Harper, J.F. The CDPK superfamily of protein kinases. New Phytol. 2001, 151, 175-183. [CrossRef] 
77. Valmonte, G.R.; Arthur, K.; Higgins, C.M.; MacDiarmid, R.M. Calcium-dependent protein kinases in plants: Evolution, expression and function. Plant Cell Physiol. 2014, 55, 551-569. [CrossRef] [PubMed]

78. Sanders, D.; Pelloux, J.; Brownlee, C.; Harper, J.F. Calcium at the crossroads of signaling. Plant Cell 2002, 14, S401-S417. [CrossRef] [PubMed]

79. Hashimoto, K.; Kudla, J. Calcium decoding mechanisms in plants. Biochimie 2011, 93, 2054-2059. [CrossRef] [PubMed]

80. Xu, W.; Huang, W. Calcium-dependent protein kinases in phytohormone signaling pathways. Int. J. Mol. Sci. 2017, 18, 2436. [CrossRef] [PubMed]

81. Harper, J.; Sussman, M.; Schaller, G.; Putnam-Evans, C.; Charbonneau, H.; Harmon, A. A calcium-dependent protein kinase with a regulatory domain similar to calmodulin. Science 1991, 252, 951-954. [CrossRef] [PubMed]

82. Wang, L.; Yu, C.; Xu, S.; Zhu, Y.; Huang, W. Osdi19-4 acts downstream of oscdpk14 to positively regulate aba response in rice. Plant Cell Environ. 2016, 39, 2740-2753. [CrossRef] [PubMed]

83. Almadanim, M.C.; Alexandre, B.M.; Rosa, M.T.G.; Sapeta, H.; Leitão, A.E.; Ramalho, J.C.; Lam, T.T.; Negrão, S.; Abreu, I.A.; Oliveira, M.M. Rice calcium-dependent protein kinase oscpk17 targets plasma membrane intrinsic protein and sucrose-phosphate synthase and is required for a proper cold stress response. Plant Cell Environ. 2017, 40, 1197-1213. [CrossRef] [PubMed]

84. Zou, J.-J.; Wei, F.-J.; Wang, C.; Wu, J.-J.; Ratnasekera, D.; Liu, W.-X.; Wu, W.-H. Arabidopsis calcium-dependent protein kinase cpk10 functions in abscisic acid- and $\mathrm{Ca}^{2+}$-mediated stomatal regulation in response to drought stress. Plant Physiol. 2010, 154, 1232-1243. [CrossRef] [PubMed]

85. Ronzier, E.; Corratge-Faillie, C.; Sanchez, F.; Prado, K.; Briere, C.; Leonhardt, N.; Thibaud, J.B.; Xiong, T.C. Cpk13, a noncanonical $\mathrm{Ca}^{2+}$-dependent protein kinase, specifically inhibits kat2 and kat1 shaker k+ channels and reduces stomatal opening. Plant Physiol. 2014, 166, 314-326. [CrossRef] [PubMed]

86. Li, L.Q.; Li, J.; Chen, Y.; Lu, Y.F.; Lu, L.M. De novo transcriptome analysis of tobacco seedlings and identification of the early response gene network under low-potassium stress. Genet. Mol. Res. 2016, 15. [CrossRef] [PubMed]

87. Ma, T.-L.; Wu, W.-H.; Wang, Y. Transcriptome analysis of rice root responses to potassium deficiency. BMC Plant Biol. 2012, 12, 161. [CrossRef] [PubMed]

88. McCormack, E.; Tsai, Y.C.; Braam, J. Handling calcium signaling: Arabidopsis cams and cmls. Trends Plant Sci. 2005, 10, 383-389. [CrossRef] [PubMed]

89. Lewit-Bentley, A.; Réty, S. Ef-hand calcium-binding proteins. Curr. Opin. Struc. Biol. 2000, 10, 637-643. [CrossRef]

90. Grabarek, Z. Structural basis for diversity of the ef-hand calcium-binding proteins. J. Mol. Biol. 2006, 359, 509-525. [CrossRef] [PubMed]

91. Hurley, R.L.; Anderson, K.A.; Franzone, J.M.; Kemp, B.E.; Means, A.R.; Witters, L.A. The $\mathrm{Ca}^{2+}$ /calmodulin-dependent protein kinase kinases are AMP-activated protein kinase kinases. J. Biol. Chem. 2005, 280, 29060-29066. [CrossRef] [PubMed]

92. Miller, J.B.; Pratap, A.; Miyahara, A.; Zhou, L.; Bornemann, S.; Morris, R.J.; Oldroyd, G.E.D. Calcium/calmodulin-dependent protein kinase is negatively and positively regulated by calcium, providing a mechanism for decoding calcium responses during symbiosis signaling. Plant Cell 2013, 25, 5053-5066. [CrossRef] [PubMed]

93. Poovaiah, B.W.; Du, L.; Wang, H.; Yang, T. Recent advances in calcium/calmodulin-mediated signaling with an emphasis on plant-microbe interactions. Plant Physiol. 2013, 163, 531-542. [CrossRef] [PubMed]

94. Zeng, H.; Xu, L.; Singh, A.; Wang, H.; Du, L.; Poovaiah, B.W. Involvement of calmodulin and calmodulin-like proteins in plant responses to abiotic stresses. Front. Plant Sci. 2015, 6, 600. [CrossRef] [PubMed]

95. Yu, T.; Zhi, G.; Shi, J.; Chen, Y.; Shen, M.; Lu, C. The calmodulin gene amcam from ammopiptanthus mongolicus confers freezing and heat tolerance in escherichia coli. Plant Growth Regul. 2017, 1-10. [CrossRef]

96. Bender, K.W.; Rosenbaum, D.M.; Vanderbeld, B.; Ubaid, M.; Snedden, W.A. The arabidopsis calmodulin-like protein, $\mathrm{cml39}$, functions during early seedling establishment. Plant J. 2013, 76, 634-647. [CrossRef] [PubMed]

97. Wu, X.; Qiao, Z.; Liu, H.; Acharya, B.R.; Li, C.; Zhang, W. Cml20, an arabidopsis calmodulin-like protein, negatively regulates guard cell aba signaling and drought stress tolerance. Front. Plant Sci. 2017, 8, 824. [CrossRef] [PubMed] 
98. Wang, S.S. Arabidopsis thaliana $\mathrm{cml} 25$ mediates the $\mathrm{Ca}^{2+}$ regulation of $\mathrm{k}+$ transmembrane trafficking during pollen germination and tube elongation. Plant Cell Environ. 2015, 38, 2372-2386. [CrossRef] [PubMed]

99. Lu, L.; Chen, Y.; Lu, L.; Lu, Y.; Li, L. Transcriptome analysis reveals dynamic changes in the gene expression of tobacco seedlings under low potassium stress. J. Genet. 2015, 94, 397-406. [CrossRef] [PubMed]

100. Brauer, E.K.; Ahsan, N.; Dale, R.; Kato, N.; Coluccio, A.E.; Piñeros, M.A.; Kochian, L.V.; Thelen, J.J.; Popescu, S.C. The raf-like kinase ilk1 and the high affinity $\mathrm{k}+$ transporter hak 5 are required for innate immunity and abiotic stress response. Plant Physiol. 2016, 171, 1470-1484. [CrossRef] [PubMed]

101. Liu, J.; Zhu, J.-K. A calcium sensor homolog required for plant salt tolerance. Science 1998, 280, $1943-1945$. [CrossRef] [PubMed]

102. Li, L.; Kim, B.G.; Cheong, Y.H.; Pandey, G.K.; Luan, S. A $\mathrm{Ca}^{2+}$ signaling pathway regulates a k+ channel for low-k response in arabidopsis. Proc. Natl. Acad. Sci. USA 2006, 103, 12625-12630. [CrossRef] [PubMed]

103. Lee, S.C.; Lan, W.Z.; Kim, B.G.; Li, L.; Cheong, Y.H.; Pandey, G.K.; Lu, G.; Buchanan, B.B.; Luan, S. A protein phosphorylation/dephosphorylation network regulates a plant potassium channel. Proc. Natl. Acad. Sci. USA 2007, 104, 15959-15964. [CrossRef] [PubMed]

104. Liu, L.-L.; Ren, H.-M.; Chen, L.-Q.; Wang, Y.; Wu, W.-H. A protein kinase, calcineurin b-like protein-interacting protein kinase9, interacts with calcium sensor calcineurin b-like protein 3 and regulates potassium homeostasis under low-potassium stress in arabidopsis. Plant Physiol. 2013, 161, 266-277. [CrossRef] [PubMed]

105. Lu, T.; Zhang, G.; Sun, L.; Wang, J.; Hao, F. Genome-wide identification of cbl family and expression analysis of cbls in response to potassium deficiency in cotton. PeerJ 2017, 5, e3653. [CrossRef] [PubMed]

106. Batistic, O.; Kudla, J. Plant calcineurin b-like proteins and their interacting protein kinases. Biochim. Biophys. Acta 2009, 1793, 985-992. [CrossRef] [PubMed]

107. Luan, S.; Kudla, J.; Rodriguez-Concepcion, M.; Yalovsky, S.; Gruissem, W. Calmodulins and calcineurin b-like proteins. Plant Cell 2002, 14, S389-S400. [CrossRef] [PubMed]

108. Kolukisaoglu, U.; Weinl, S.; Blazevic, D.; Batistic, O.; Kudla, J. Calcium sensors and their interacting protein kinases: Genomics of the arabidopsis and rice cbl-cipk signaling networks. Plant Physiol. 2004, 134, 43-58. [CrossRef] [PubMed]

109. Zhu, S.; Zhou, X.; Wu, X.; Jiang, Z. Structure and function of the cbl-cipk Ca ${ }^{2+}$-decoding system in plant calcium signaling. Plant Mol. Biol. Rep. 2013, 31, 1193-1202. [CrossRef]

110. Sanchez-Barrena, M.J.; Martinez-Ripoll, M.; Zhu, J.K.; Albert, A. The structure of the arabidopsis thaliana sos3: Molecular mechanism of sensing calcium for salt stress response. J. Mol. Biol. 2005, 345, 1253-1264. [CrossRef] [PubMed]

111. Sanchez-Barrena, M.J.; Fujii, H.; Angulo, I.; Martinez-Ripoll, M.; Zhu, J.K.; Albert, A. The structure of the c-terminal domain of the protein kinase atsos2 bound to the calcium sensor atsos3. Mol. Cell 2007, 26, 427-435. [CrossRef] [PubMed]

112. Weinl, S.; Kudla, J. The cbl-cipk $\mathrm{Ca}^{2+}$-decoding signaling network: Function and perspectives. New Phytol. 2009, 184, 517-528. [CrossRef] [PubMed]

113. Luan, S. The cbl-cipk network in plant calcium signaling. Trends Plant Sci. 2009, 14, 37-42. [CrossRef] [PubMed]

114. Thoday-Kennedy, E.L.; Jacobs, A.K.; Roy, S.J. The role of the cbl-cipk calcium signalling network in regulating ion transport in response to abiotic stress. Plant Growth Regul. 2015, 76, 3-12. [CrossRef]

115. Sanyal, S.K.; Pandey, A.; Pandey, G.K. The cbl-cipk signaling module in plants: A mechanistic perspective. Physiol. Plant. 2015, 155, 89-108. [CrossRef] [PubMed]

116. Mao, J.; Manik, S.M.; Shi, S.; Chao, J.; Jin, Y.; Wang, Q.; Liu, H. Mechanisms and physiological roles of the cbl-cipk networking system in arabidopsis thaliana. Genes 2016, 7, 62. [CrossRef] [PubMed]

117. Batistic, O.; Sorek, N.; Schultke, S.; Yalovsky, S.; Kudla, J. Dual fatty acyl modification determines the localization and plasma membrane targeting of CBL/CIPK $\mathrm{Ca}^{2+}$ signaling complexes in arabidopsis. Plant Cell 2008, 20, 1346-1362. [CrossRef] [PubMed]

118. Yu, Y.; Xia, X.; Yin, W.; Zhang, H. Comparative genomic analysis of CIPK gene family in arabidopsis and populus. Plant Growth Regul. 2007, 52, 101-110. [CrossRef]

119. Mohanta, T.K.; Mohanta, N.; Mohanta, Y.K.; Parida, P.; Bae, H. Genome-wide identification of calcineurin b-like (cbl) gene family of plants reveals novel conserved motifs and evolutionary aspects in calcium signaling events. BMC Plant Biol. 2015, 15, 189. [CrossRef] [PubMed] 
120. Yin, X.; Wang, Q.; Chen, Q.; Xiang, N.; Yang, Y.; Yang, Y. Genome-wide identification and functional analysis of the calcineurin b-like protein and calcineurin b-like protein-interacting protein kinase gene families in turnip (brassica rapa var. Rapa). Front. Plant Sci. 2017, 8, 1191. [CrossRef] [PubMed]

121. Batistic, O.; Waadt, R.; Steinhorst, L.; Held, K.; Kudla, J. Cbl-mediated targeting of cipks facilitates the decoding of calcium signals emanating from distinct cellular stores. Plant J. 2010, 61, 211-222. [CrossRef] [PubMed]

122. Zhu, J.-K.; Liu, J.; Xiong, L. Genetic analysis of salt tolerance in arabidopsis: Evidence for a critical role of potassium nutrition. Plant Cell 1998, 10, 1181-1191. [CrossRef] [PubMed]

123. Halfter, U.; Ishitani, M.; Zhu, J.K. The arabidopsis sos2 protein kinase physically interacts with and is activated by the calcium-binding protein sos3. Proc. Natl. Acad. Sci. USA 2000, 97, 3735-3740. [CrossRef] [PubMed]

124. Liu, J.; Ishitani, M.; Halfter, U.; Kim, C.S.; Zhu, J.K. The arabidopsis thaliana sos2 gene encodes a protein kinase that is required for salt tolerance. Proc. Natl. Acad. Sci. USA 2000, 97, 3730-3734. [CrossRef] [PubMed]

125. Halford, N.G.; Hey, S.J. Snf1-related protein kinases (snrks) act within an intricate network that links metabolic and stress signalling in plants. Biochem. J. 2009, 419, 247-259. [CrossRef] [PubMed]

126. Coello, P.; Hey, S.J.; Halford, N.G. The sucrose non-fermenting-1-related (snrk) family of protein kinases: Potential for manipulation to improve stress tolerance and increase yield. J. Exp. Bot. 2011, 62, 883-893. [CrossRef] [PubMed]

127. Williams, S.P.; Rangarajan, P.; Donahue, J.L.; Hess, J.E.; Gillaspy, G.E. Regulation of sucrose non-fermenting related kinase 1 genes in arabidopsis thaliana. Front. Plant Sci. 2014, 5, 324. [CrossRef] [PubMed]

128. Zhou, X.; Hao, H.; Zhang, Y.; Bai, Y.; Zhu, W.; Qin, Y.; Yuan, F.; Zhao, F.; Wang, M.; Hu, J.; et al. Sos2-like protein kinase5, an snf1-related protein kinase3-type protein kinase, is important for abscisic acid responses in arabidopsis through phosphorylation of abscisic acid-insensitive5. Plant Physiol. 2015, 168, 659-676. [CrossRef] [PubMed]

129. Guo, Y.; Halfter, U.; Ishitani, M.; Zhu, J.-K. Molecular characterization of functional domains in the protein kinase sos2 that is required for plant salt tolerance. Plant Cell 2001, 13, 1383-1400. [CrossRef] [PubMed]

130. Gong, D.; Guo, Y.; Jagendorf, A.T.; Zhu, J.K. Biochemical characterization of the arabidopsis protein kinase sos2 that functions in salt tolerance. Plant Physiol. 2002, 130, 256-264. [CrossRef] [PubMed]

131. Guo, Y.; Qiu, Q.-S.; Quintero, F.J.; Pardo, J.M.; Ohta, M.; Zhang, C.; Schumaker, K.S.; Zhu, J.-K. Transgenic evaluation of activated mutant alleles of sos2 reveals a critical requirement for its kinase activity and c-terminal regulatory domain for salt tolerance in arabidopsis thaliana. Plant Cell 2004, 16, 435-449. [CrossRef] [PubMed]

132. Gong, D.; Gong, Z.; Guo, Y.; Zhu, J.K. Expression, activation, and biochemical properties of a novel arabidopsis protein kinase. Plant Physiol. 2002, 129, 225-234. [CrossRef] [PubMed]

133. Gong, D.; Gong, Z.; Guo, Y.; Chen, X.; Zhu, J.K. Biochemical and functional characterization of pks11, a novel arabidopsis protein kinase. J. Biol. Chem. 2002, 277, 28340-28350. [CrossRef] [PubMed]

134. Gao, P.; Kolenovsky, A.; Cui, Y.; Cutler, A.J.; Tsang, E.W.T. Expression, purification and analysis of an arabidopsis recombinant cbl-interacting protein kinase3 (cipk3) and its constitutively active form. Protein Expr. Purif. 2012, 86, 45-52. [CrossRef] [PubMed]

135. Fujii, H.; Zhu, J.K. An autophosphorylation site of the protein kinase sos2 is important for salt tolerance in arabidopsis. Mol. Plant 2009, 2, 183-190. [CrossRef] [PubMed]

136. Tang, R.J.; Yang, Y.; Yang, L.; Liu, H.; Wang, C.T.; Yu, M.M.; Gao, X.S.; Zhang, H.X. Poplar calcineurin b-like proteins ptcbl10a and ptcbl10b regulate shoot salt tolerance through interaction with ptsos2 in the vacuolar membrane. Plant Cell Environ. 2014, 37, 573-588. [CrossRef] [PubMed]

137. Sanyal, S.K.; Kanwar, P.; Samtani, H.; Kaur, K.; Jha, S.K.; Pandey, G.K. Alternative splicing of cipk3 results in distinct target selection to propagate aba signaling in arabidopsis. Front. Plant Sci. 2017, 8, 1924. [CrossRef] [PubMed]

138. Ohta, M.; Guo, Y.; Halfter, U.; Zhu, J.K. A novel domain in the protein kinase sos2 mediates interaction with the protein phosphatase 2c abi2. Proc. Natl. Acad. Sci. USA 2003, 100, 11771-11776. [CrossRef] [PubMed]

139. Sanchez-Barrena, M.J.; Martinez-Ripoll, M.; Albert, A. Structural biology of a major signaling network that regulates plant abiotic stress: The cbl-cipk mediated pathway. Int. J. Mol. Sci. 2013, 14, 5734-5749. [CrossRef] [PubMed] 
140. Xiao, D.; Cui, Y.; Xu, F.; Xu, X.; Gao, G.; Wang, Y.; Guo, Z.; Wang, D.; Wang, N.N. Senescence-suppressed protein phosphatase directly interacts with the cytoplasmic domain of senescence-associated receptor-like kinase and negatively regulates leaf senescence in arabidopsis. Plant Physiol. 2015, 169, 1275-1291. [CrossRef] [PubMed]

141. Krzywińska, E.; Kulik, A.; Bucholc, M.; Fernandez, M.A.; Rodriguez, P.L.; Dobrowolska, G. Protein phosphatase type 2c pp2ca together with abi1 inhibits snrk2.4 activity and regulates plant responses to salinity. Plant Signal. Behav. 2016, 11, e1253647. [CrossRef] [PubMed]

142. Manohar, M.; Wang, D.; Manosalva, P.M.; Choi, H.W.; Kombrink, E.; Klessig, D.F. Members of the abscisic acid co-receptor pp2c protein family mediate salicylic acid-abscisic acid crosstalk. Plant Direct 2017, 1, e00020. [CrossRef]

143. Cheong, Y.H.; Pandey, G.K.; Grant, J.J.; Batistic, O.; Li, L.; Kim, B.-G.; Lee, S.-C.; Kudla, J.; Luan, S. Two calcineurin b-like calcium sensors, interacting with protein kinase cipk23, regulate leaf transpiration and root potassium uptake in arabidopsis. Plant J. 2007, 52, 223-239. [CrossRef] [PubMed]

144. Lagarde, D.; Basset, M.; Lepetit, M.; Conejero, G.; Gaymard, F.; Astruc, S.; Grignon, C. Tissue-specific expression of arabidopsis akt1 gene is consistent with a role in k+ nutrition. Plant J. 1996, 9, 195-203. [CrossRef] [PubMed]

145. Hirsch, R.E.; Lewis, B.D.; Spalding, E.P.; Sussman, M.R. A role for the akt1 potassium channel in plant nutrition. Science 1998, 280, 918-921. [CrossRef] [PubMed]

146. Spalding, E.P.; Hirsch, R.E.; Lewis, D.R.; Qi, Z.; Sussman, M.R.; Lewis, B.D. Potassium uptake supporting plant growth in the absence of akt1 channel activity: Inhibition by ammonium and stimulation by sodium. J. Gen. Physiol. 1999, 113, 909-918. [CrossRef] [PubMed]

147. Gierth, M.; Mäser, P.; Schroeder, J.I. The potassium transporter athak5 functions in k+ deprivation-induced high-affinity $\mathrm{k}+$ uptake and akt1 k+ channel contribution to $\mathrm{k}+$ uptake kinetics in arabidopsis roots. Plant Physiol. 2005, 137, 1105-1114. [CrossRef] [PubMed]

148. Pyo, Y.J.; Gierth, M.; Schroeder, J.I.; Cho, M.H. High-affinity k+ transport in arabidopsis: Athak5 and akt1 are vital for seedling establishment and postgermination growth under low-potassium conditions. Plant Physiol. 2010, 153, 863-875. [CrossRef] [PubMed]

149. Nieves-Cordones, M.; Alemán, F.; Martínez, V.; Rubio, F. K+ uptake in plant roots. The systems involved, their regulation and parallels in other organisms. J. Plant Physiol. 2014, 171, 688-695. [CrossRef] [PubMed]

150. Jeanguenin, L.; Alcon, C.; Duby, G.; Boeglin, M.; Chérel, I.; Gaillard, I.; Zimmermann, S.; Sentenac, H.; Véry, A.-A. Atkc1 is a general modulator of arabidopsis inward shaker channel activity. Plant J. 2011, 67, 570-582. [CrossRef] [PubMed]

151. Wang, X.-P.; Chen, L.-M.; Liu, W.-X.; Shen, L.-K.; Wang, F.-L.; Zhou, Y.; Zhang, Z.; Wu, W.-H.; Wang, Y. Atkc1 and cipk23 synergistically modulate akt1-mediated low-potassium stress responses in arabidopsis. Plant Physiol. 2016, 170, 2264-2277. [CrossRef] [PubMed]

152. Marten, I.; Hoth, S.; Deeken, R.; Ache, P.; Ketchum, K.A.; Hoshi, T.; Hedrich, R. Akt3, a phloem-localized k+ channel, is blocked by protons. Proc. Natl. Acad. Sci. USA 1999, 96, 7581-7586. [CrossRef] [PubMed]

153. Lacombe, B.; Pilot, G.; Michard, E.; Gaymard, F.; Sentenac, H.; Thibaud, J.-B. A shaker-like k+ channel with weak rectification is expressed in both source and sink phloem tissues of arabidopsis. Plant Cell 2000, 12, 837-852. [PubMed]

154. Chérel, I.; Michard, E.; Platet, N.; Mouline, K.; Alcon, C.; Sentenac, H.; Thibaud, J.-B. Physical and functional interaction of the arabidopsis k+ channel akt2 and phosphatase atpp2ca. Plant Cell 2002, 14, 1133-1146. [CrossRef] [PubMed]

155. Michard, E.; Dreyer, I.; Lacombe, B.; Sentenac, H.; Thibaud, J.-B. Inward rectification of the akt2 channel abolished by voltage-dependent phosphorylation. Plant J. 2005, 44, 783-797. [CrossRef] [PubMed]

156. Michard, E.; Lacombe, B.; Porée, F.; Mueller-Roeber, B.; Sentenac, H.; Thibaud, J.-B.; Dreyer, I. A unique voltage sensor sensitizes the potassium channel akt2 to phosphoregulation. J. Gen. Physiol. 2005, 126, 605-617. [CrossRef] [PubMed]

157. Adams, E.; Shin, R. Transport, signaling, and homeostasis of potassium and sodium in plants. J. Integr. Plant Biol. 2014, 56, 231-249. [CrossRef] [PubMed]

158. Kim, M.J.; Ruzicka, D.; Shin, R.; Schachtman, D.P. The arabidopsis ap2/erf transcription factor rap2.11 modulates plant response to low-potassium conditions. Mol. Plant 2012, 5, 1042-1057. [CrossRef] [PubMed] 
159. Walker, D.J.; Leigh, R.A.; Miller, A.J. Potassium homeostasis in vacuolate plant cells. Proc. Natl. Acad. Sci. USA 1996, 93, 10510-10514. [CrossRef] [PubMed]

160. Ahn, S.J.; Shin, R.; Schachtman, D.P. Expression of kt/kup genes in arabidopsis and the role of root hairs in k+ uptake. Plant Physiol. 2004, 134, 1135-1145. [CrossRef] [PubMed]

161. Zhao, S.; Zhang, M.L.; Ma, T.L.; Wang, Y. Phosphorylation of arf2 relieves its repression of transcription of the $\mathrm{k}+$ transporter gene hak5 in response to low potassium stress. Plant Cell 2016, 28, 3005-3019. [CrossRef] [PubMed] 